\title{
The Politics of Rescuing the World's Financial System: The Federal Reserve as a Global Lender of Last Resort
}

\author{
J. Lawrence Broz
}

During the financial crisis of 2007-10, the Federal Reserve (Fed) served as a global lender of last resort by establishing currency swap agreements with 14 foreign central banks, including several in East Asia. These agreements were controversial internationally because the Fed selectively established swaps with some central banks and not others, raising concerns about access to the Fed's dollar-creating facilities. Within the United States, the swap agreements were controversial because they appeared to be a new and unauthorized kind of foreign aid to bankers. I analyze both the Fed's decision to establish swap lines with certain central banks and the domestic political response to these agreements. I find that the Fed was more likely to establish swaps with central banks whose jurisdictions were important to U.S. commercial banks, suggesting that the Fed discriminated in ways that served U.S. interests. To analyze the domestic reaction to the foreign currency swaps, I examine voting in the House of Representatives on a proposal known as "Audit the Fed" that would open the Fed's relations with foreign central banks to scrutiny and reduce the Fed's independence from Congress. I find that campaign contributions from large commercial banks to representatives were negatively correlated with voting "yes" on this proposal. I also find that right-wing representatives were much more likely to support this proposal than left-wing representatives, which suggests that new congressional coalitions are forming on the role of the Fed in the (global) economy.

Key Words: Federal Reserve, central banking, international financial crisis, currency swap agreements

*J. Lawrence Broz (jlbroz@ucsd.edu) is Professor of Political Science at the University of California, San Diego. Professor Broz received his PhD in political science from the University of California, Los Angeles (1993) and has held faculty appointments at Harvard University (1993-2000) and New York University (2000-2001). He is the author of International Origins of the Federal Reserve System (1997) and co-author of two edited volumes on international political economy. His recent articles have appeared in a number of top journals, including the American Journal of Political Science and International Organization.

This paper was presented at the KJIS International Conference in Seoul, South Korea on December 5, 2014. Previous drafts were presented at the London School of Economics and Political Science on March 6, 2014; at the University of California, Riverside on December 5, 2013; at the Politics of the Changing World Economy conference in Goa, India on January 5, 2013; at the International Political Economy Society (IPES) conference on November 9, 2012; and at Nuffield College, Oxford University on October 5, 2012. I thank all conference participants and discussants for their helpful feedback. I also thank Maya Oren for excellent research assistance and Cheryl Schonhardt-Bailey, Jeffry Frieden, Thomas Pepinsky, Christina Schneider, Stephen Weymouth, Taehee Whang, Laurence Whitehead, and Kevin Young for detailed comments.

The Korean J ournal of International Studies Vol.13-2 (August 2015), 323-351.

http://dx.doi.org/10.14731/kjis.2015.08.13.2.323

(c) 2015 The Korean Association of International Studies 
D uring the financial crisis of 2007-2010, the Federal Reserve (Fed) served as a global lender of last resort providing dollar liquidity to foreign banks with significant dollar-denominated exposures. Through bilateral agreements known as "Central Bank Liquidity Swap Lines," the Fed channeled over half a trillion dollars to foreign central banks, which then used the dollars to provide liquidity to private financial institutions in their jurisdictions. As the only central bank capable of providing an unlimited supply of dollars, the Fed became the world's de facto lender of last resort.

The Fed's foreign lending generated political controversy both at home and abroad. The international concern was that the Fed established swap agreements selectively and provided little transparency with respect to the criteria that it used to determine whether a foreign central bank would receive a swap line or not (Aizenman and Pasricha 2010; Aizenman, Yothin and Park 2011). Selectivity meant that a majority of countries did not have access to the Fed's swap facilities, implying that they are essentially on their own in defending themselves against future financial market shocks. Selectivity, in the absence of transparency about the selection process, also implied that Fed swap lines could not reliably substitute for reserve accumulation or dependence on the International Monetary Fund (Aizenman, Yothin and Park 2011; Obstfeld, Shambaugh and Taylor 2009). This ambiguity was reinforced in October 2013 when the Fed announced that it was selectively institutionalizing a portion of its global network of swap agreements by converting temporary arrangements with five central banks into permanent standing agreements. ${ }^{1}$ This decision left other central banks, particularly in East Asia, wondering why they had been excluded from this privileged group and whether they would be denied access to Fed swap facilities in the future (Destais 2014; Sheng 2014).

In the first half of this paper, I analyze the Fed's selection of 14 foreign central banks for swap agreements between 2007 and 2010. I focus on the swap agreements because the Fed's main policymaking body, the Federal Open Market Committee (FOMC), had discretion over which central banks to select for these facilities. By contrast, the Fed's domestic crisis facilities and its discount window were open to any private bank - foreign or domestic - that was a member of the Federal Reserve System. Currency swaps with foreign central banks were policy choices and the Fed usually made these decisions after a foreign central bank had requested a swap agreement (United States General Accountability Office 2011, 118). I gather information on the criteria the FOMC used to evaluate these

\footnotetext{
${ }^{1}$ According to the Fed's press release, swap agreements with the Bank of Canada, the Bank of England, the European Central Bank, the Bank of Japan, and the Swiss National Bank are permanent.
} 
requests from the GAO and from the minutes of the FOMC and I find some empirical support for the Fed's stated criteria. ${ }^{2}$ However, I also find that the strongest correlate of a central bank being selected by the Fed for a swap agreement is the exposure of U.S. commercial banks to a foreign market, where "exposure" is measured as the share of the individual foreign market in the total consolidated foreign claims of U.S. money center banks. This variable alone accounts for 59 percent of the variation in the dependent variable and is robust to economic and financial controls. This correlation suggests that the Federal Reserve was motivated to serve as a lender of last resort for certain foreign countries at least in part because it served the economic and financial interests of the United States. This interpretation is consistent with Aizenman and Pasricha (2010), who focus more narrowly on the Fed's selection of four emerging market countries for swaps, and with McDowell's (2012) qualitative analysis of the Fed's foreign operations during the crisis.

Within the United States, controversy swelled over the Fed's foreign lending and contributed to a congressional backlash against the Fed's confidentiality and political independence. This reaction is important because the Federal Reserve is beholden to the U.S. Congress for its authorities and its independence and must therefore maintain congressional support to protect itself from legislative challenges (Havrilesky 1995; Grier 1991; Hetzel 1986; Kane 1982). When it was revealed that the Fed had provided more aid to foreign banks and central banks than to domestic banks, legislative pressure on the Fed intensified. 3 This pressure culminated in the Representative Ron Paul's (R-TX) "Federal Reserve Transparency Act of 2012" which would open the Fed's relations with foreign central banks to congressional scrutiny and reduce the Fed's broader independence from politics. The bill was approved in House of Representatives on July 25, 2012 by a roll-call vote of 327-98 but later blocked in the Senate by the Democratic Party leadership (Peterson and Hughes 2012).

In the second part of this paper, I analyze House voting on this bill and find that the influence of major U.S. commercial banks extends to Congress by way of campaign contributions: contributions from the largest banks are negatively correlated with the propensity of a representative to vote in favor of the bill. This result establishes a connection between the international and domestic levels of analysis as the interests of large commercial banks correlate both with the Fed's swap

\footnotetext{
2 The GAO is an independent, nonpartisan agency that works for Congress and is often called the "congressional watchdog" because its mission is to ensure the accountability of federal government agencies to Congress. The Fed is normally exempt from GAO audits but the Dodd-Frank law required the Fed to submit to a one-time GAO audit of its crisis programs and policies.

3 For a narrative of events, see Irwin (2013).
} 
line decisions and the congressional response to those global decisions.

I also uncover a surprising result of importance to the Fed's political independence: voting on Paul's "Audit the Fed" bill, as it was popularly known, marked a pronounced break with the past in terms of the ideological basis of support for the Fed in Congress. In this instance, the Left positioned itself as the defender of the Fed (by voting against the bill) while the Right attacked the Fed for generating moral hazard on a global scale and for its unconventional quantitative easing programs. All but one Republican voted in favor of the Audit the Fed proposal while Democrats split about evenly (89-97). Focusing only on Democrats, so as to eliminate the concern that election-year presidential politics influenced representatives' votes, I find that right-wing Democrats were as much as 67 percentage points more likely to vote "yes" on this bill than left-wing Democrats. In short, during the worst financial crisis since the Great Depression, the Left became the defender of the Fed's independence and confidentiality while the Right challenged it to be more transparent, more accountable, and dramatically less "global".

Section 2 provides background on the financial crisis and a summary of the Fed's global lender-of-last-resort activities. Section 3 introduces the data, models, and analyses of the Fed's currency swap arrangements. Section 4 moves to the congressional level and provides analyses of voting on the Audit the Fed proposal. Section 5 concludes with a discussion of the Fed's new support coalition in Congress and the implications for its political independence.

\section{THE FEDERAL RESERVE'S GLOBAL LENDING}

The Federal Reserve Act of 1913 gave the Fed responsibility for both setting monetary policy and for maintaining the stability of U.S. financial markets. In the latter capacity, the Fed supervises U.S. banks and foreign banks with branches in the U.S. and provides lender-of-last-resort services to these institutions during crises. Between 2007 and 2010, the Fed provided more than a trillion dollars in emergency loans to the financial sector to address the breakdown of interbank and other money markets. According to the GAO, "the scale and nature of this assistance amounted to an unprecedented expansion of the Federal Reserve System's traditional role as lender-of-last-resort" (United States General Accountability Office 2011, 1).

The programs were unprecedented partly because of their international scope. As indicated in Table 1, the largest program, measured in terms of the peak dollar amount of loans outstanding, was the Central Bank Liquidity Swap Lines pro- 
Table 1. Broad-Based Federal Reserve Emergency Programs

\begin{tabular}{|c|c|c|c|}
\hline \multirow[b]{2}{*}{ Broad-based programs } & \multicolumn{2}{|c|}{ Dollars, in billions } & \multirow[b]{2}{*}{ Description } \\
\hline & $\begin{array}{l}\text { Peak dollar } \\
\text { amount } \\
\text { outstanding }\end{array}$ & $\begin{array}{l}\text { Balance } \\
\text { as of } \\
6 / 29 / 2011\end{array}$ & \\
\hline $\begin{array}{l}\text { TAF - Term Auction Facility } \\
\text { (Dec. 12, 2007-Mar. 8, 2010) }\end{array}$ & $\$ 493$ & $\$ 0$ & $\begin{array}{l}\text { Auctioned one-month and three- } \\
\text { month discount window loans to } \\
\text { eligible depository institutions }\end{array}$ \\
\hline $\begin{array}{l}\text { Dollar Swap Lines (Dec. 12, } \\
\text { 2007-Feb. 1, 2010) }\end{array}$ & 586 & 0 & $\begin{array}{l}\text { Exchanged dollars with foreign } \\
\text { central banks for foreign curren- } \\
\text { cy to help address disruptions in } \\
\text { dollar funding markets abroad }\end{array}$ \\
\hline $\begin{array}{l}\text { TSLF - Term Securities Lending } \\
\text { Facility (Mar. 11, 2008-Feb. 1, } \\
\text { 2010) }\end{array}$ & 236 & 0 & $\begin{array}{l}\text { Auctioned loans of U.S. Treasury } \\
\text { securities to primary dealers } \\
\text { against eligible collateral }\end{array}$ \\
\hline $\begin{array}{l}\text { PDCF - Primary Dealer Credit } \\
\text { Facility (Mar. 16, 2008-Feb. 1, } \\
\text { 2010) }\end{array}$ & 130 & 0 & $\begin{array}{l}\text { Provided overnight cash loans to } \\
\text { primary dealers against eligible } \\
\text { collateral }\end{array}$ \\
\hline $\begin{array}{l}\text { AMLF - Asset-Backed } \\
\text { Commercial Paper }\end{array}$ & 152 & 0 & $\begin{array}{l}\text { Provided loans to depository } \\
\text { institutions and their affiliates to } \\
\text { finance purchases of eligible } \\
\text { asset-backed commercial paper } \\
\text { from money market mutual funds }\end{array}$ \\
\hline $\begin{array}{l}\text { CPFF - Commercial Paper } \\
\text { Funding Facility (Oct. 7, 2008- } \\
\text { Feb. 1, 2010) }\end{array}$ & 348 & 0 & $\begin{array}{l}\text { Provided loans to a special pur- } \\
\text { pose vehicle to finance purchas- } \\
\text { es of new issues of asset-backed } \\
\text { commercial paper and unse- } \\
\text { cured commercial paper from eli- } \\
\text { gible issuers }\end{array}$ \\
\hline $\begin{array}{l}\text { MMIFF - Money Market Investor } \\
\text { Funding Facility (Oct. 21, } 2008 \\
\text { but never used) }\end{array}$ & $\begin{array}{l}\text { No loans } \\
\text { provided }\end{array}$ & 0 & $\begin{array}{l}\text { Created to finance the purchase } \\
\text { of eligible short-term debt obliga- } \\
\text { tions held by money market } \\
\text { mutual funds }\end{array}$ \\
\hline $\begin{array}{l}\text { TALF - Term Asset-Backed } \\
\text { Securities Loan Facility } \\
\text { (Nov. 25, 2008-June 30, 2010) }\end{array}$ & 48 & 13 & $\begin{array}{l}\text { Provided loans to eligible } \\
\text { investors to finance purchases of } \\
\text { eligible asset-backed securities }\end{array}$ \\
\hline
\end{tabular}

Note: aDollar swap lines with the Bank of Canada, the Bank of England, the Bank of Japan, the European Central Bank, and the Swiss National Bank were reopened in May 2010 and made permanent in October 2013. Source: United States General Accounting Office (2011).

gram. But "domestic" programs, such as the Term Auction Facility (TAF) and Commercial Paper Funding Facility (CPFF) were also tapped by foreign financial institutions via their branches in the United States. As Figure 1 illustrates, branches and subsidiaries of foreign banks received more than half of the total dollar amount of TAF and CPFF loans. Foreign banks were also heavy borrowers at the Fed's discount window during the crisis. Table 2 indicates that 15 of the 30 largest borrowers at the discount window were branches or agencies of foreign banks. 
Figure 1. TAF and CPFF Borrowing by Country of the Parent Company

Term Auction Facility (TAF)

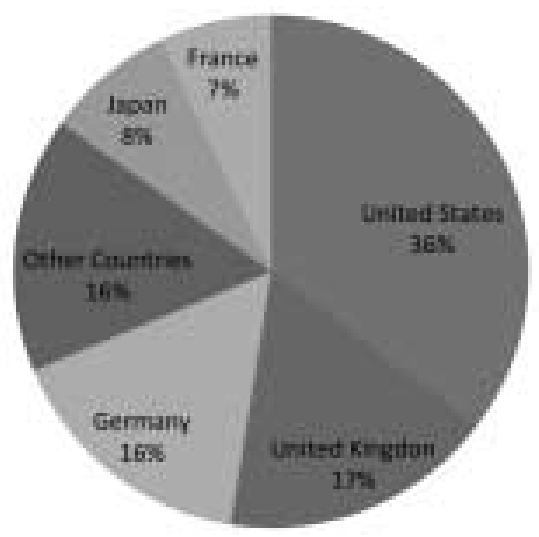

Commerical Paper Funding Facility (CPFF)

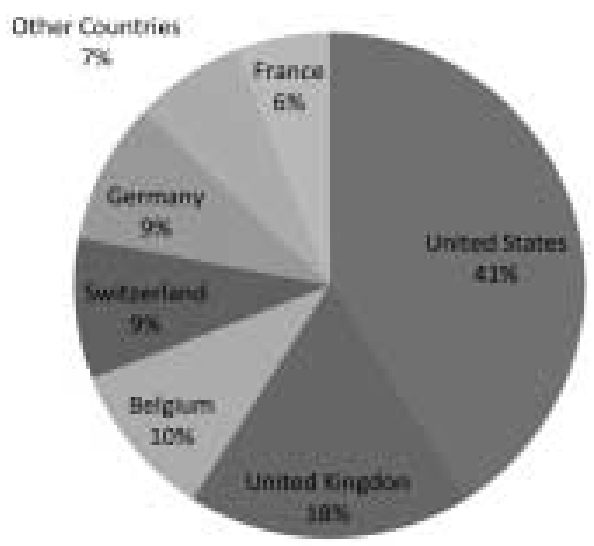

Source: Adapted from United States General Accountability Office (2011), Figure 10, p.134.

The proximate reason the Fed provided last-resort loans to non-U.S. banks was that foreign banks experienced severe funding shortages in U.S. dollars after interbank markets froze in October 2008 (Shin 2012; Ivashina et al. 2012; Goldberg et al. 2011; McGuire and von Peter 2009; Allen and Moessner 2010; Fleming and Klagge 2010). These dollar shortages were a direct outgrowth of the explosive growth of cross-border banking since 2000. Foreign banks, particularly European banks, began accumulating large amounts of dollar-denominated assets, including subprime Mortgage-Backed Securities (MBS), via the shadow banking system. Dollar-denominated assets of banks outside the U.S. peaked at $\$ 10$ trillion before the crisis, an amount equal to the total assets of the U.S. commercial banking sector (Shin 2012). Those were the dollar assets on their books. But foreign banks had a similar amount of dollar liabilities because they had funded their dollar asset positions in short-term U.S. wholesale markets, particularly by borrowing dollars from U.S. money market mutual funds. Given their reliance on U.S. wholesale markets for dollar funding, foreign banks were vulnerable to losses on their long-dated and illiquid dollar-denominated subprime assets. When wholesale dollar funding markets froze after the Lehman Brothers bankruptcy in October 2008, foreign banks could not roll over their dollar liabilities. Although the resulting dollar liquidity crisis affected both U.S. and foreign banks, it was particularly acute for foreign banks since they did not hold significant U.S. dollar deposits and relied more heavily on the wholesale and swap markets to fund their dollar-denominated assets. In short, the rapid expansion of cross-bor- 
der borrowing and lending in U.S. dollars placed the Federal Reserve in the unprecedented position of having to provide dollar liquidity to banks throughout the globally-integrated financial system.

Table 2. Top Thirty Borrowers at the Fed's Discount Window, August 2007 to April 2010

\begin{tabular}{|c|c|c|c|c|}
\hline Rank & $\begin{array}{c}\text { Origination } \\
\text { Date }\end{array}$ & Borrower & $\begin{array}{l}\text { Maturity } \\
\text { Date }\end{array}$ & $\begin{array}{c}\text { Peak } \\
\text { Borrowing } \\
\text { (Billions } \\
\text { USD) }\end{array}$ \\
\hline 1 & $10 / 1 / 2008$ & AIG & $9 / 22 / 2010$ & 61.00 \\
\hline 2 & $10 / 29 / 2008$ & CPFF & $1 / 27 / 2009$ & 56.56 \\
\hline 3 & 9/26/2008 & BANK OF NY MELLON & 9/29/2008 & 44.11 \\
\hline 4 & $12 / 31 / 2008$ & DEXIA CREDIT LOCAL NY BR (Belgium) & $1 / 5 / 2009$ & 37.00 \\
\hline 5 & $11 / 6 / 2008$ & DEPFA BK PLC NY BR (Ireland) & $11 / 7 / 2008$ & 28.50 \\
\hline 6 & $3 / 28 / 2008$ & JPMORGAN CHASE BK NA & $3 / 31 / 2008$ & 28.50 \\
\hline 7 & $10 / 6 / 2008$ & WACHOVIA BK NA & $1 / 2 / 2009$ & 23.00 \\
\hline 8 & $10 / 6 / 2008$ & ROYAL BK OF SCOTLAND PLC NY B (United Kingdom) & $10 / 7 / 2008$ & 8.40 \\
\hline 9 & $3 / 27 / 2008$ & BANK OF NY & $3 / 28 / 2008$ & 7.50 \\
\hline 10 & $10 / 14 / 2008$ & SOVEREIGN BK & $10 / 15 / 2008$ & 7.26 \\
\hline 11 & $9 / 29 / 2008$ & FORTIS BK SA/NV NY BR (Belgium) & $9 / 30 / 2008$ & 6.96 \\
\hline 12 & $11 / 24 / 2008$ & US CENTRAL FCU & $11 / 25 / 2008$ & 6.00 \\
\hline 13 & 9/17/2008 & BANK OF SCOTLAND PLC NY BR (United Kingdom) & $10 / 17 / 2008$ & 5.00 \\
\hline 14 & 9/19/2008 & SOCIETE GENERALE NY BR (France) & $12 / 18 / 2008$ & 4.00 \\
\hline 15 & $10 / 8 / 2008$ & MS CO & $10 / 9 / 2008$ & 3.63 \\
\hline 16 & $5 / 28 / 2008$ & ERSTE BK OESTERREICHISCH NY BR (Austria) & $6 / 6 / 2008$ & 3.50 \\
\hline 17 & $10 / 9 / 2008$ & MORGAN STANLEY BK NA & $10 / 14 / 2008$ & 3.25 \\
\hline 18 & $6 / 30 / 2008$ & DEUTSCHE BK AG NY BR (Germany) & $7 / 1 / 2008$ & 3.04 \\
\hline 19 & $3 / 28 / 2008$ & CALYON NY BR (France) & $4 / 4 / 2008$ & 3.00 \\
\hline 20 & 9/16/2008 & NORINCHUKIN BK NY BR (Japan) & $12 / 15 / 2008$ & 3.00 \\
\hline 21 & $12 / 22 / 2008$ & WESTERN CORP FCU & $12 / 23 / 2008$ & 2.75 \\
\hline 22 & $5 / 19 / 2008$ & HSH NORDBK AG NY BR (Germany) & $8 / 15 / 2008$ & 2.50 \\
\hline 23 & 9/18/2008 & LANDESBK BADEN WUERTTEMB NY (Germany) & $10 / 16 / 2008$ & 2.50 \\
\hline 24 & $3 / 31 / 2008$ & RBS CITIZENS NA & $4 / 1 / 2008$ & 2.24 \\
\hline 25 & $10 / 7 / 2008$ & COMMERZBANK AG NY BR (Germany) & $1 / 5 / 2009$ & 2.00 \\
\hline 26 & 9/18/2008 & WASHINGTON MUT BK & $9 / 22 / 2008$ & 2.00 \\
\hline 27 & $6 / 20 / 2008$ & BANK OF AMER NA & $6 / 23 / 2008$ & 1.70 \\
\hline 28 & $4 / 10 / 2008$ & BNP PARIBAS EQUITABLE TOWER B (France) & $4 / 11 / 2008$ & 1.64 \\
\hline 29 & 9/22/2008 & ABCP - JPMORGAN CHASE BK & 9/29/2008 & 1.15 \\
\hline 30 & $9 / 29 / 2008$ & BANK TOK-MIT UFJ NY BR (Japan) & $10 / 8 / 2008$ & 1.00 \\
\hline
\end{tabular}

Note: The country of domicile for foreign banks is indicated in parentheses. These data are from Bloomberg News, which compiled the Fed's court-ordered discount window data into spreadsheets. Accessed from http://www.bloomberg.com/news/2011-12-23/fed-s-once-secret-data-compiled-by-bloomberg-released-topublic.html (February 12, 2012). 
In response to the global dollar liquidity crisis, the Fed simultaneously established two programs: the TAF and the central bank swaps. While the TAF addressed domestic dollar funding pressures, the Fed recognized that the new facility was unlikely to alleviate dollar funding pressures overseas since interbank lending was effectively frozen and foreign central banks' could not create dollars (typically, central banks lend to domestic banks in domestic currency). Although U.S. branches of foreign banks could borrow dollars from the Fed, many foreign banks could not. The Fed stepped in by offering dollar swap lines to foreign central banks, which enabled these central banks to provide dollar liquidity to banks within their jurisdictions. According to Bordo, "These swap lines essentially extended the Term Auction Facility's reach beyond U.S. borders by financing term dollar funding facilities for foreign banks" (Bordo et al. 2012, 8).

As indicated in Table 3, the Fed approved temporary swap lines with 14 central banks between December 2007 and October 2008. These central banks used the U.S. dollars obtained through the swap lines to make dollar loans to private financial institutions in their jurisdictions. The foreign central banks assumed the risk of losses on these dollar loans and paid the Fed interest (Fleming and Klagge 2010).

Table 3. Federal Reserve Dollar Liquidity Swap Lines with Foreign Central Banks

\begin{tabular}{l|r|r|r}
\hline \multicolumn{1}{c|}{ Foreign Central Bank (date announced) } & $\begin{array}{c}\text { Number of } \\
\text { Transactions }\end{array}$ & $\begin{array}{c}\text { Peak Amount } \\
\text { (Billions USD) }\end{array}$ & $\begin{array}{c}\text { Peak Trade } \\
\text { Date }\end{array}$ \\
\hline European Central Bank (12/12/2007) & 271 & 170.93 & Oct 15 2008 \\
\hline Bank of England (09/18/2008) & 114 & 96.31 & Oct 152008 \\
\hline Bank of Japan (09/18/2008) & 35 & 50.17 & Oct 212008 \\
\hline Swiss National Bank (12/12/2007) & 81 & 13.11 & Jan 13 2009 \\
\hline Danmarks Nationalbank (09/24/2008) & 19 & 10.00 & Oct 24 2008 \\
\hline Sveriges Riksbank (09/24/2008) & 18 & 10.00 & Oct 15 2008 \\
\hline Reserve Bank of Australia (09/24/2008) & 10 & 10.00 & Sep 26 2008 \\
\hline Norges Bank (09/24/2008) & 8 & 7.05 & Jan 27 2009 \\
\hline Bank of Korea (10/29/2008) & 10 & 4.00 & Dec 2 2008 \\
\hline Banco de Mexico (10/29/2008) & 3 & 3.22 & Apr 212009 \\
\hline Bank of Canada (09/18/2008) & 0 & 0 & \\
\hline Reserve Bank of New Zealand (10/28/2008) & 0 & 0 & \\
\hline Banco Central do Brasil (10/29/2008) & 0 & 0 & - \\
\hline Monetary Authority of Singapore (10/29/2008) & 0 & 0 & - \\
\hline
\end{tabular}

Note: These data cover the swap agreements that ran between December 1, 2007 and February 1, 2010. Peak amount represents the largest dollar swap transaction under the arrangement. Peak trade date indicates the date the largest swap took place. The central banks of Canada, New Zealand, Brazil, and Singapore did not draw on their swap lines. Accessed at http://www.federalreserve.gov/newsevents/reform_swaplines.htm (July 1, 2012). 
Figure 2 illustrates how these swap agreement worked. The following example provides a case study: In its first currency swap with the European Central Bank (ECB), the Fed exchanged $\$ 10$ billion for an equivalent value of euros ( $€ 6.93$ billion at the prevailing exchange rate of $\mathbf{1 . 4 4 2}$ dollars per euro). The ECB then lent those dollars to Eurozone banks that were suffering from a dollar shortage. There was no exchange-rate risk for the Fed since the exchange rate was fixed at the time of the agreement. Moreover, the ECB assumed all the credit risk on the dollar loans it made to private banks. While the "tenor" (number of days until the swap matured) varied, this particular swap matured in 28 days and required the ECB to pay the Fed an interest rate of 4.65 percent during that period. At maturity, the ECB returned $\$ 10$ billion to the Fed and the Fed returned $€ 6.934$ billion to the $\mathrm{ECB}$, closing out the transaction. The process was repeated until the dollar shortage crisis abated in early 2010. During that time, the Fed conducted 271 separate swap transactions with the ECB, totaling $\$ 171$ billion in currency swaps.

Figure 2. Federal Reserve Dollar Swap Agreements

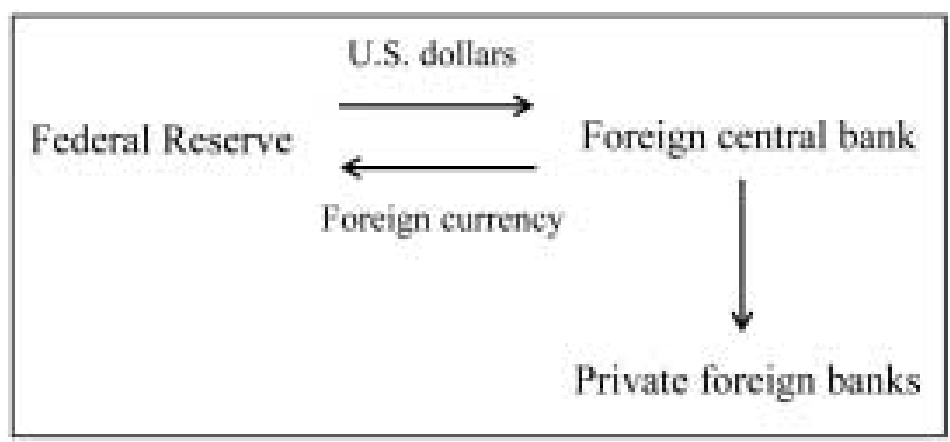

Note: In a swap agreement, the Federal Reserve temporarily provides a foreign central bank with U.S. dollars in exchange for foreign currency at a fixed exchange rate and receives a fee. The foreign central bank then lends those dollars to private institutions in its jurisdiction on a collateralized basis and assumes the credit risk.

Dollars outstanding to all 14 foreign central banks peaked at $\$ 586$ billion in December 2008, with the ECB accounting for about 80 percent of total dollars drawn. By most accounts, the swaps were successful in channeling dollar liquidity abroad, signaling central bank cooperation, and calming markets (Goldberg et al. 2011; Baba et al. 2009; Obstfeld et al. 2009; Obstfeld 2009). The initial swap lines expired in February 2010 but the Fed reauthorized the swap lines with five central banks in May 2010 in response to strains in dollar funding markets associated with the Eurozone debt crisis. In October 2013, these five swap agreements were made permanent. Figure 3 shows the outstanding value of the Fed's dollar 
swaps to June 2013. I focus on the Fed swaps conducted during the subprime crisis because of their larger scale and because they involved central banks from nearly every region of the world.

Figure 3. Central Bank Liquidity Swaps held by the Federal Reserve

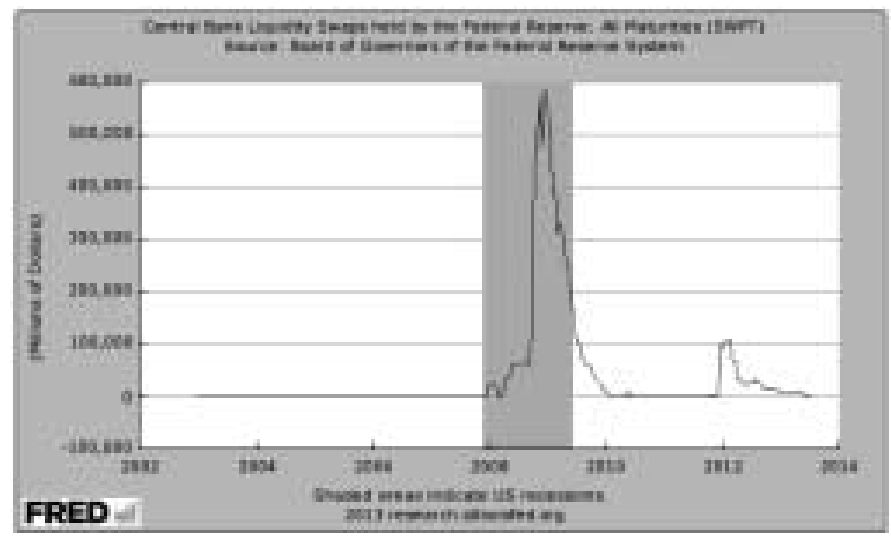

Source: FRED, Federal Reserve Economic Data, Federal Reserve Bank of St. Louis: Central Bank Liquidity Swaps [SWPT]; Board of Governors of the Federal Reserve System. Accessed at

http://research.stlouisfed.org/fred2/series/SWPT (August 7, 2013).

How did the Federal Reserve determine which central banks to select for swap lines? We know from the GAO audit of the program that establishing a swap line required a request from a foreign central bank and approval by the FOMC: "The FOMC's consideration of a new swap line arrangement generally followed a request from an interested foreign central bank, but not all requests were granted." (United States General Accountability Office 2011, 118). While the names of the central banks that were denied swap lines by the FOMC are not public knowledge, the GAO did reveal the criteria the FOMC said it used to evaluate these requests. Based on internal memorandums and communication with Federal Reserve Board staff, the GAO found that the FOMC's approval of swap line requests "were generally based on the economic and financial mass of the country's economy, a record of sound economic management, and the probability that the swap line would make an economic difference." The GAO audit also noted that "the swap line arrangements were generally made with foreign central banks of important U.S. trading partners or global financial centers, such as Switzerland, Japan, and England, based on global funding needs.” Further insight into the selection of central banks comes from FOMC member William Poole, President of the Federal Reserve Bank of St. Louis. Poole voted against establishing swap 
lines with the ECB and the Swiss National Bank on that the grounds that these central banks held large foreign currency reserves, including dollars, that could be used to backstop dollar liquidity in Europe (Minutes 11, December 2007).

The broader point is that the Fed selected central banks for swap lines on the basis of certain economic and financial considerations. Yet political exigencies may also have influenced the Fed's list of criteria (Irwin 2013, 154-155). For example, the Fed may have realized that its massive lending to foreign banks and central banks would smack of "foreign aid," which is always controversial in Congress, and therefore tried emphasize the national interest. 4 This could explain why the FOMC included a country's importance as trading partner on its list of criteria. A "record of sound economic management" may also have been included for a similar reason: if the Fed had conducted a swap with a foreign central bank that was generally viewed as incompetent or untrustworthy, such as the central bank of Peru or Russia, it might be hard to justify the swap to Congress. Then again, FOMC officials may simply have been concerned about the ability of foreign central bankers to carry out dollar liquidity operations on behalf of the Fed. In this view, which Irwin (2013, 153-155) espouses, FOMC officials viewed central banks that had demonstrated competence in macroeconomic management as more reliable partners.

The FOMCs selection criteria can be evaluated empirically and, in the analysis below, I control for these considerations in an effort to isolate the association between private bank interests and the Fed's choice of central banks for swap agreements.

\section{CORRELATES OF THE FED'S CENTRAL BANK SWAP ARRANGEMENTS}

My measure of cross-country variation in the Fed's foreign decisions during the crisis is SWAP LINE, an indicator variable equal to 1 if the Fed selected a country or central bank jurisdiction for a dollar swap line during the crisis, o otherwise. I draw on the FOMC's swap line selection criteria to estimate the economic, financial, and potentially political covariates of the Fed's foreign lending during the crisis. I also consider the loan exposures of U.S. commercial banks to foreign markets in the analyses. Previous research has shown that large U.S. banks comprise

\footnotetext{
${ }^{4}$ Irwin $(2013,154)$ reports that "The scale of lending to foreign banks was a closely guarded secret even by standards of the always secretive Fed. During the panic, this information was so closely heldand had it been known publically, so potentially explosive-that only two people at each of the dozen reserve banks were allowed access to it."
} 
a key constituency for international last-resort lenders such as the International Monetary Fund (IMF) and the U.S. Treasury Department's Exchange Stabilization Fund (Broz 2007; Broz 2005; Gould 2003). This is because such last-resort lending ensures that the countries in which these banks are highly exposed are protected under the lender's insurance umbrella.

Beyond their size, the crucial feature that distinguishes large money-center banks from other banks is that that engage in international lending. In fact, just eleven banks account for almost all the foreign loans extended by U.S. financial institutions. According to data from the Federal Financial Institutions Examination Council, the following banks accounted for 93 percent of all the consolidated foreign claims of U.S. banks in 2007: Bank of America, Bank of New York, Citigroup, Deutsche Bank (Taunus Corp.), HSBC, JPMorgan Chase, State Street, Wachovia, and Wells Fargo. 5

The concentrated nature of foreign lending suggests a simple hypothesis: large U.S. banks would prefer to have the Fed extend swap agreements to countries in which they are most heavily exposed. Without access to dollar funding via Fed currency swaps, private foreign banks needing to rollover their dollar liabilities would have been severely impaired, necessitating the abrupt forced sale of their dollar assets. This deleveraging of dollar assets would have exacerbated problems for U.S. banks, which had counterparty relationships with foreign banks. With a mandate to protect the stability of the U.S. financial system, the Federal Reserve may have selectively targeted foreign central banks for bilateral swap arrangements, favoring those that were more important to the financial interests of the United States and discriminating against those that were less important. The relevant implication is that not all central banks could expect help from the Federal Reserve during periods of global financial turmoil.

My measure of this influence is BANK EXPOSURE which is the value of consolidated claims of U.S. banks on individual countries divided by the consolidated claims of U.S. banks on all countries in December 2007. ${ }^{6}$ These data highlight the role of large financial institutions located in the nation's money centers (i.e., "money center banks") because these large banks conduct almost all the nation's international lending. My argument is that U.S. money center banks benefit when the Fed provides dollar liquidity to foreign countries in which they are highly exposed. The bank exposure variable ranges from zero, indicating that U.S. banks had no financial claims on a country's financial and non-financial institutions in

\footnotetext{
${ }^{5}$ Federal Financial Institutions Examination Council Statistical Release E.16, December 31, 2007.

${ }^{6}$ Bank of International Settlements (BIS), Consolidated Banking Statistics, Table 9B, Foreign claims by nationality of reporting banks, immediate borrower basis.
} 
2007, to maximum of 0.24 for the Eurozone, indicating that U.S. banks had extended nearly one-quarter of their total foreign loans to Eurozone institutions.

Table 4 reports the results of probit regressions of SWAP LINE on BANK EXPOSURE and controls. Since the ECB received a swap line for all members of the Eurozone, I code a single observation for the ECB and sum (or average, where appropriate) covariate values of the 12 Eurozone member countries in 2007. The results show a positive and significant BANK EXPOSURE estimate across all four models, which is consistent with Aizenman and Pasricha's (2010) results for the smaller group of emerging market nations. In Model 1, this covariate alone accounts for 59 percent of the variation in the data. However, without knowing the names of all the foreign central banks that approached the Fed for swap lines, we cannot infer whether greater exposure of U.S. money center banks increased the likelihood that a central bank would request a swap line from the FOMC or whether larger bank exposures increased the likelihood the FOMC would grant a

Table 4. Fed's Selection of Foreign Central Banks for Dollar Swap Lines

\begin{tabular}{|c|c|c|c|c|}
\hline & $\begin{array}{c}\text { (1) } \\
\text { Swap Line }\end{array}$ & $\begin{array}{c}\text { (2) } \\
\text { Swap Line }\end{array}$ & $\begin{array}{c}\text { (3) } \\
\text { Swap Line }\end{array}$ & $\begin{array}{c}\text { (4) } \\
\text { Swap Line }\end{array}$ \\
\hline Bank Exposure (\% world) & $\begin{array}{c}0.070 * * * \\
(0020)\end{array}$ & $\begin{array}{c}0.110^{* * *} \\
(0.026)\end{array}$ & $\begin{array}{l}0.102^{* \star *} \\
(0.031)\end{array}$ & $\begin{array}{l}0.049^{* * *} \\
(0.015)\end{array}$ \\
\hline GDP (\% world) & & $\begin{array}{l}98.117^{*} \\
(56.492)\end{array}$ & $\begin{array}{l}50.128 \\
(63.961)\end{array}$ & $\begin{array}{l}-14.882 \\
(20.244)\end{array}$ \\
\hline Liquid Liabilities (\% world) & & $\begin{array}{c}-71.434^{\star * *} \\
(21.541)\end{array}$ & $\begin{array}{c}-59.348^{* *} \\
(25.660)\end{array}$ & \\
\hline $\begin{array}{l}\text { Bilateral Trade } \\
\text { (\% total U.S. trade) }\end{array}$ & & $\begin{array}{l}-12.218 \\
(15.422)\end{array}$ & $\begin{array}{c}-4.053 \\
(16.236)\end{array}$ & \\
\hline Inflation (ave 1997-2007) & & $\begin{array}{c}-0.960^{* * *} \\
(0.258)\end{array}$ & $\begin{array}{c}-1.094^{* * *} \\
(0.381)\end{array}$ & $\begin{array}{c}-0.362^{* *} \\
(0.146)\end{array}$ \\
\hline Reserves ( $\%$ of GDP) & & $\begin{array}{l}-2.879^{* * *} \\
(0.955)\end{array}$ & $\begin{array}{l}-3.642^{\star \star} \\
(1.486)\end{array}$ & \\
\hline Dollar Shortages & & & $\begin{array}{l}-0.006 \\
(0.005)\end{array}$ & $\begin{array}{l}-0.030^{\star *} \\
(0.013)\end{array}$ \\
\hline Global Financial Center & & & & $\begin{array}{l}4.299^{*} \\
(2.393)\end{array}$ \\
\hline Constant & $\begin{array}{c}-2.202^{* * *} \\
(0.231)\end{array}$ & $\begin{array}{c}0.629 \\
(0.647) \\
\end{array}$ & $\begin{array}{l}2.311^{*} \\
(1.286)\end{array}$ & $\begin{array}{l}-0.232 \\
(0.628)\end{array}$ \\
\hline Observations & 149 & 116 & 33 & 39 \\
\hline Pseudo R-Squared & 0.59 & 0.79 & 0.75 & 0.62 \\
\hline P-Value & 0.000 & 0.000 & 0.015 & 0.006 \\
\hline Log Pseudolikelihood & -18.85 & -8.274 & -5.459 & -9.687 \\
\hline Wald Chi-Squared & 12.38 & 32.12 & 17.26 & 16.08 \\
\hline
\end{tabular}

Robust standard errors in parentheses; ${ }^{*} p<0.10,{ }^{* *} p<0.05,{ }^{* * *} p<0.01$

Note: The dependant variable is SWAP LINE which equals 1 if the FOMC selected a foreign central bank for a dollar swap arrangement, 0 otherwise. Since the ECB received a swap line, I code a single observation for the Eurozone and then sum (or average, where appropriate) covariate values for its twelve member countries in 2007. 
swap line once it was requested.

Models 2-4 provide some evidence in support of the Fed's selection criteria. The set of controls is derived from the GAO's audit, during which FOMC members and Federal Reserve staff described the factors that shaped their selection of countries for swap lines. In Model 2, I control for a country's "economic mass" with its share of world GDP (GDP divided by world GDP, in billions USD, 2007), and a country's "financial mass" with its share of world LIQUID LIABILITIES (liquid liabilities divided by total world liquid liabilities, in billions USD, 2007).7 Liquid liabilities (M3) is the broadest available indicator of the extent of financial intermediation and therefore a suitable proxy for a country's financial importance or "mass".

In Model 2, the estimate for GDP share is positive and significant at the 10 percent level. This gives some credence to the FOMC's claim that it considered the "economic mass" of a country (or central bank jurisdiction) when allocating swap lines. However, GDP share is not significant in Model 3 and incorrectly signed and not significant in Model 4. LIQUID LIABILITIES share is significant in Models 2 and 3 but wrongly signed, given the FOMC's claim about how it allocated swap lines. It appears that countries with greater shares of the world's total financial intermediation were less likely to participate in a swap arrangement with the Fed. Perhaps financially-important countries were less likely to need (and therefore request) a swap line from the Fed. Or perhaps the Fed was less likely to grant such requests when they came from financially-important countries. Without knowing the full list of countries that approached the Fed for assistance, we can't discriminate between these accounts. But the result cuts against the Fed's claim that it considered "financial mass" when it established swaps.

Models 2 and 3 introduce BILATERAL TRADE share, which is a country's trade (imports and exports) with the United States as a share of total U.S. imports plus exports in 2007. ${ }^{8}$ The sign on this estimated effect of BILATERAL TRADE share in both models is negative but not significant, which is consistent with Aizenman and Pasricha's (2010) result for the smaller set of emerging market nations. There is little evidence that the Fed's swap decisions were based on U.S. trade relationships. 9

Models 2-4 control for INFLATION, which is a proxy for the FOMC's concern with the competence of a central bank and its "record of sound economic man-

\footnotetext{
${ }^{7}$ For the Eurozone, I sum the values of the twelve countries under the ECB's jurisdiction in 2007. Data are from the World Economic Outlook (WEO) Database and Beck et al (2000).

8 Data from Barbieri and Keshk (2012).

${ }^{9}$ Substituting U.S. exports to a country as a share of total U.S. exports produces similar results.
} 
agement." When a central bank presides over stable and low inflation, the Fed may have been more likely to view is it as a credible partner in extending dollar liquidity to local banks. INFLATION is measured as the annual percentage change in CPI inflation averaged over the previous decade (1997-2007). ${ }^{10}$ In all three models, the INFLATION estimate is negative and significant suggesting that the FOMC did considered "sound economic management" as a criterion for selection. Countries with higher average inflation rates over the prior decade were less likely to receive a swap agreement with the Fed. ${ }^{11}$ This is consistent with the characterization of central banks as competent "subcontractors" for the Fed, providing dollar lender-of-last-resort services in foreign jurisdictions (Obstfled 2009). Models 2 and 3 also control for a central bank's foreign currency reserves with RESERVES, in line with William Poole's concern that the Fed should not grant swap facilities to central banks with large international reserves. RESERVES are measured as a central bank's total international reserves (excluding gold) as a share of GDP. ${ }^{12}$ Although the currency composition of official reserves is not available, it is fair to assume that currency reserves correlate closely with U.S. dollar reserves since the dollar is the world's dominant reserve currency. The estimates in Models 2 and 3 suggest that Poole's argument was relevant to selection: central banks with large official reserves were less likely to obtain a swap agreement with the Fed. But, as before, we cannot infer whether large reserves reduced the likelihood that a foreign central bank would approach the Fed for a swap line or whether large reserves reduced the odds the Fed would grant a swap line once it was requested.

Evaluating a foreign jurisdiction dollar shortage - a key FOMC criterion - is limited by data availability to a smaller sample of countries. Models 3 and 4 controls for the "dollar funding needs" of banks in foreign countries with DOLLAR SHORTAGES, which is constructed from the Bank of International Settlements (BIS) Locational Banking Statistics following Allen and Moessner (2010). The BIS collects data on the currency-specific claims and liabilities of banks for a subset of 39 reporting countries. Although this dramatically reduces the sample size in Models 3 and 4, it does provide a fairly accurate measure of dollar funding needs. DOLLAR SHORTAGES is measured as the net outstanding U.S. dollar cross-border claims on BIS reporting banks and non-banks in a country/jurisdiction in December 2008, where "net" is defined as total dollar cross-border lia-

\footnotetext{
${ }^{10}$ Inflation data are from the IMF's International Financial Statistics.

${ }^{11}$ Alternative measures of central bank credibility, including measures of "central bank independence," do not perform as well as the actual price level data.

12 These data are from the IMF's International Financial Statistics, series RAXGFX.
} 
bilities minus claims in all foreign and domestic currencies at the end of 2008. By this measure, the largest dollar liquidity shortage was in the United Kingdom ($\$ 153.6$ billion), which was the largest borrower from the Federal Reserve during the crisis. Since negative values indicate dollar shortages, I expect the estimated effect of DOLLAR SHORTAGES to be negative.

While the estimate of DOLLAR SHORTAGES is negative as expected in both models, it is significant only in Model 4. GLOBAL FINANCIAL CENTER is an indicator variable equal to 1 if a country is home to a global financial center city.13 The DOLLAR SHORTAGE estimate is negative and significant in this model, which accords with the Fed's criterion: countries with "greater need" of dollar liquidity were more likely to get a swap line from the Fed. GLOBAL FINANCIAL CENTER also enters positively and significantly, which supports the Fed's statements on this criterion.

Despite the introduction of controls and changes in sample size, the estimate on BANK EXPOSURE remains positive and significance across all four models in Table 4. To get a sense of the magnitude of the effect, Figure 4 plots the predictive margins and confidence intervals of receiving a Fed swap line from Model 3, holding covariates to their means while increasing BANK EXPOSURE from its minimum to its maximum value. The figure illustrates the substantively large effect of U.S. bank exposure on the probability of receiving a Fed swap line. When U.S. money center banks have $\$ 1$ billion in claims on a country's residents, the chance of participating in a Fed swap is just 13 percent. But when U.S. banks hold $\$ 41$ billion in claims on a country's residents, the probability of getting a Fed swap rises to 57 percent, a 44 percentage point increase. The loan exposure of U.S. banks appears to be a good predictor of Fed swaps. However, the available data do not allow us to determine whether high loan exposures made it more likely that a foreign central bank would ask the Fed for a swap agreement or whether the Fed was more likely to grant a request once it was made.

${ }^{13}$ The Global Financial Centres Index designates Toronto, Frankfurt Hong Kong, Japan, Singapore, Zurich, and London as "global financial centers." 
Figure 4. Marginal Effects of Bank Exposure on Swap Line Selection

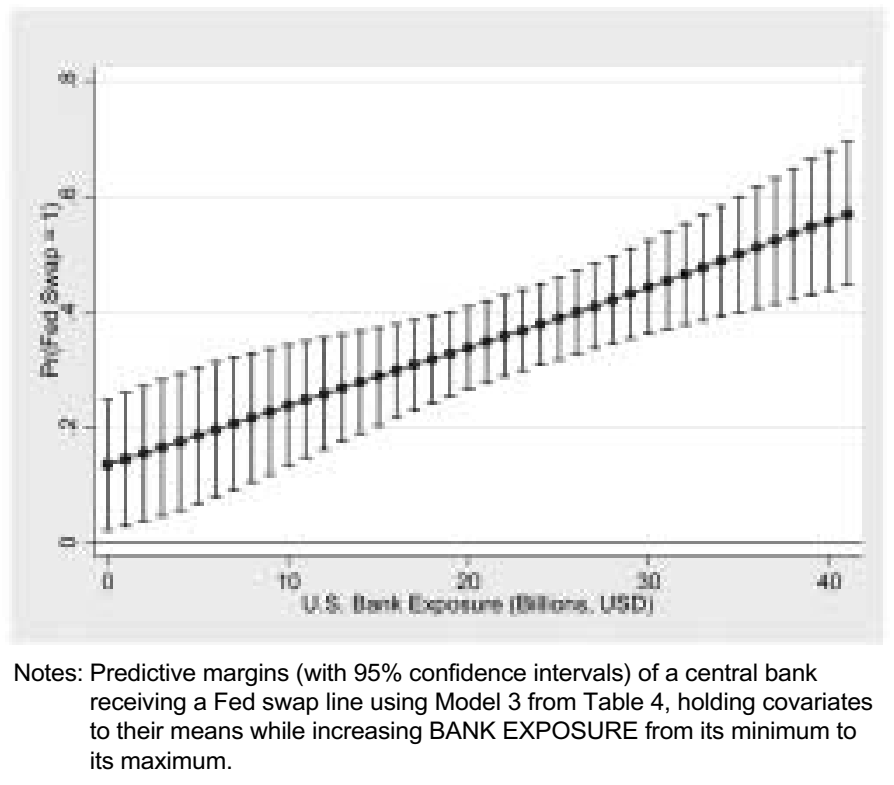

\section{CONGRESSIONAL VOTING ON RON PAUL'S "AUDIT THE FED" PROPOSAL}

In this section, I analyze congressional voting on Representative Ron Paul's, The Federal Reserve Transparency Act of 2012. My main goal is to see if the influence of commercial banks extends to the U.S. Congress, the political body with formal authority over the Fed. I also explore the nature of the support coalition in Congress that backs the Fed and protects it from legislative challenges. Congress created the Fed and conducts regular oversight of its congressionallydelegated authority; thus, the Fed is beholden to Congress and must maintain sufficient congressional support in order to protect its independence and its authorities.

Ron Paul, the sponsor of the bill, was outraged by Fed's global policies: "I am surprised and deeply disturbed to learn the staggering amount of money that went to foreign banks. These lending activities provided no benefit to American taxpayers, the American economy, or even directly to American banks" (Felsenthal and Zargham 2011). According to the congressional report that accompanied his bill to the floor, the bill would allow the GAO to audit: "(1) 
Transactions for or with a foreign central bank, foreign government or international financing agency; (2) Deliberations, decisions, or actions on monetary policy matters, including discount window operations, reserves of member banks, securities credit, interest on deposits, and open market operations; (3) Transactions made under the direction of the Federal Open Market Committee; and (4) Any discussions or communications among or between members of the Federal Reserve Board of Governors and officers and employees of the Federal Reserve System related to the above."14 Elijah Cummings (D-MD) wrote the minority opinion section of the report and argued that the bill would critically undermine the political independence of the Federal Reserve.

The vote was taken under a procedure called "suspension of the rules" which is typically used to pass non-controversial bills since votes under suspension require two-thirds majority. The tally of 327-98 easily met this threshold. All Republicans except Robert Turner (R-NY) voted in favor of the bill, but Democrats were divided, with 89 Democrats joining Republicans to approve the bill and 97 voting against. While election-year politics probably had some impact on voting, it is noteworthy that Republicans - the traditional supporters of the Fed's independence - voted en masse for the bill while Democrats - the party that usually attacks the Fed as an unaccountable power with incestuous relations with banks - lined up as the Fed's protector. In a striking indicator of this reversal, Democratic Whip Steny Hoyer (D-MD) implored Democrats to vote "no" on the grounds that the proposal "impedes the independence of this critical institution... House Republicans cannot be allowed to hold our economy or our critical economic institutions hostage in order to further their extreme agenda."15

The whip was not effective as almost half of the Democrats broke ranks and voted with Republicans. I analyze Democrats' vote choice on this bill with an eye toward gauging the influence of money center banks and identifying the personal and constituency factors that contribute to legislators' decisions. While previous research has shown that campaign contributions from large banks shape vote choices in other areas, such as funding for the IMF and foreign aid, I extend this analysis to voting on "Audit the Fed" (Broz 2011, Milner and Tingley 2011). My measure is BANK CONTRIBUTIONS, operationalized as campaign contributions from money center banks' Political Action Committees (PACs) to representatives during the two election cycles prior to the vote, divided by total contributions a representative received from all sources during these two cycles. My expectation

\footnotetext{
${ }^{14}$ Accessed at www.gpo.gov/fdsys/pkg/CRPT-112hrpt607/pdf/CRPT-112hrpt607-pt1.pdf (July $1,2012)$.

${ }^{15}$ Office of the Democratic Whip Steny Holler.
} 
is that representatives that are more dependent on banks for campaign contributions are more likely to vote against the bill.

I identify "money center banks" from the FFIEC's list of "Large Financial Institutions" that account for over 90 percent of all foreign banking claims held by U.S. banks. ${ }^{16}$ The banks comprising this group are: Bank of America, Bank of New York, Citigroup, Deutsche Bank (Taunus Corp.), HSBC, JP Morgan Chase, State Street, Wachovia, and Wells Fargo. Deutsche Bank and HSBC are foreignowned banks with branches in the U.S. and each has a PAC that contributes to congressional campaigns. This measure thus captures the role that large banks play in Congress via contributions to campaigns.

Model 1 in Table 5 reports results of a probit model regression of Democrats' voting on the bill. The BANK CONTRIBUTIONS estimate is negative and statistically significant suggesting that ties to banks through the contributions channel help protect the Fed from legislative challenges. Model 2 controls for the political "ideology" of representatives using the first dimension DW-NOMINATE score, which is derived from a spatial model of representatives' individual roll-call voting histories. As Poole and Rosenthal (2000) explain, the first dimension can be interpreted as a representative's position on government intervention in the economy. Values range from -1 to 1 , with higher values indicating a more rightwing, anti-government ideology. The estimate in Model 2 suggests that rightleaning Democrats are more likely than left-leaning Democrats to support auditing the Fed. ${ }^{17}$

\footnotetext{
${ }^{16}$ See fn 5 .

${ }^{17}$ House members' ideology is at least partly a reflection of the ideology of House district constituencies (Levendusky, Pope and Jackman 2008; Canes-Wrone, Cogan and Brady 2002).
} 
Table 5. House Voting on Ron Paul's "Audit the Fed" Bill

\begin{tabular}{|c|c|c|c|c|c|}
\hline & $\begin{array}{c}\text { (1) } \\
\text { Dems }\end{array}$ & $\begin{array}{c}(2) \\
\text { Dems }\end{array}$ & $\begin{array}{c}\text { (3) } \\
\text { Dems }\end{array}$ & $\begin{array}{c}\text { (4) } \\
\text { Dems }\end{array}$ & $\begin{array}{l}\text { (5) } \\
\text { All }\end{array}$ \\
\hline Bank Contributions & $\begin{array}{c}-71.374^{* * *} \\
(26.214)\end{array}$ & $\begin{array}{c}-98.493^{* * *} \\
(28.541)\end{array}$ & $\begin{array}{c}-94.135^{\star \star *} \\
(28.700)\end{array}$ & $\begin{array}{c}-100.912^{\star \star *} \\
(35.028)\end{array}$ & $\begin{array}{c}-95.293^{\star * *} \\
(27.059)\end{array}$ \\
\hline DW-Nominate & & $\begin{array}{l}3.659^{\star \star *} \\
(0.848)\end{array}$ & $\begin{array}{l}3.618^{\star * *} \\
(0.880)\end{array}$ & $\begin{array}{c}3.108^{* * *} \\
(0.935)\end{array}$ & $\begin{array}{c}3.544^{\star \star *} \\
(0.551)\end{array}$ \\
\hline Social Security & & & $\begin{array}{c}1.683 \\
(2.831)\end{array}$ & $\begin{array}{c}1.840 \\
(2.976)\end{array}$ & $\begin{array}{c}1.651 \\
(2.950)\end{array}$ \\
\hline Foreclosure Rate & & & $\begin{array}{c}13.335 \\
(15.613)\end{array}$ & $\begin{array}{c}12.174 \\
(16.050)\end{array}$ & $\begin{array}{c}12.332 \\
(16.280)\end{array}$ \\
\hline Bank HQ & & & & $\begin{array}{l}-0.046 \\
(0.665)\end{array}$ & $\begin{array}{l}-0.057 \\
(0.663)\end{array}$ \\
\hline Chamber Seniority & & & & $\begin{array}{c}-0.048^{* *} \\
(0.021)\end{array}$ & $\begin{array}{c}-0.045^{\star \star} \\
(0.019)\end{array}$ \\
\hline Finance Committee & & & & $\begin{array}{c}0.158 \\
(0.323)\end{array}$ & $\begin{array}{c}0.152 \\
(0.306)\end{array}$ \\
\hline Constant & $\begin{array}{c}0.085 \\
(0.107)\end{array}$ & $\begin{array}{l}1.570^{* * *} \\
(0.353)\end{array}$ & $\begin{array}{l}1.201^{*} \\
(0.653)\end{array}$ & $\begin{array}{l}1.313^{*} \\
(0.672)\end{array}$ & $\begin{array}{l}1.487^{* *} \\
(0.596)\end{array}$ \\
\hline Observations & 186 & 185 & 185 & 182 & 416 \\
\hline Pseudo R2 & 0.025 & 0.117 & 0.121 & 0.143 & 0.518 \\
\hline P-Value & 0.0064 & 0.0000 & 0.0000 & 0.0000 & 0.0000 \\
\hline Log Pseudo-likelihood & -125.6 & -113.0 & -112.5 & -107.9 & -108.4 \\
\hline Wald Chi2 & 7.413 & 26.95 & 26.59 & 35.28 & 59.09 \\
\hline
\end{tabular}

Robust standard errors in parentheses ${ }^{*} p<0.10,{ }^{* *} p<0.05,{ }^{* * *} p<0.01$

Note: The dependant variable is VOTE, a member's vote on "Audit the Fed" where "yes" $=1$ and "no" $=0$. Probit Models 1-4 are for Democrats only. Model 5 is for all representatives. DW-Nominate uses roll-call voting records to measures the "left-right" ideology of representatives and ranges from -1 to 1 , with higher values indicating a more right-wing ideology. See the text for the definitions of other variables.

However, factors other than ideology may have contributed to the Right's attack on the Fed. For example, if older, home-owning constituents were especially hard hit by the subprime crisis and also more likely to be right-wing, these estimates might be subject to omitted variable bias. As retired homeowners living on their savings, these constituents may have had a material basis for criticizing the Fed. They held the Fed partially responsible for causing the crisis, since easy credit conditions early in the cycle facilitated the housing boom. The subsequent bust devastated older citizens who saw their primary nest eggs - their homes - plummet in value just as the Fed's stimulus programs dramatically reduced the return on retiree savings.

To control for the possibility that opposition to the Fed among right-leaning constituents is based on these material considerations, Model 3 includes SOCIAL SECURITY, which is the share of a district's population receiving OASDI benefits, and FORECLOSURE RATE, which is the share of a district's private housing 
stock in foreclosure. ${ }^{18}$ The estimates are both positively signed but not significant. ${ }^{19}$ Given that estimated effect of DW-NOMINATE remains virtually unchanged, it is fair to conclude that ideology is driving representatives' voting, not the hardships endured by older constituents during the crisis. I consider the implications of this finding in the conclusion.

In Model 4, I control for additional factors to ensure that estimates on bank campaign contributions and member ideology are not spurious. BANK HQ is an indicator variable equal to 1 if a representative's district is home to the headquarters to one of the nation's eleven money center banks. I expected a negative sign but the estimate is positive and not significant. CHAMBER SENIORITY counts the number of terms representatives have served in the House. The estimate is negative and significant, indicating that more senior Democrats were less likely to support the bill, in line with their party's whip. FINANCE COMMITTEE is an indicator variable equal to 1 if a representative sits on the House Financial Services Committee. ${ }^{20}$ Membership on this committee may be correlated with bank contributions since interest groups are known to bestow larger contributions on legislators with greater influence over their industries. The estimate is positive but not significant. Model 5 applies the same analysis to voting by all representatives, Democrats and Republicans. The estimates are very similar to those in Model 4.

${ }^{18}$ The source for the social security data is the U.S. Social Security Administration, Office of Retirement and Disability Policy, Office of Research, Evaluation, and Statistics, December 2010. Foreclosure data are from the real estate listing service Hotpads.

${ }^{19}$ The results are nearly identical when the share of a district's population aged 65 and over is used in place of the share of social security beneficiaries. The two measures are highly correlated $(\mathrm{r}=$ 0.85 ).

${ }^{20}$ Data on seniority and committee membership are from Stewart and Woon (2011). 
Figure 5. Marginal Effects of Bank Contributions on "Audit the Fed" Voting

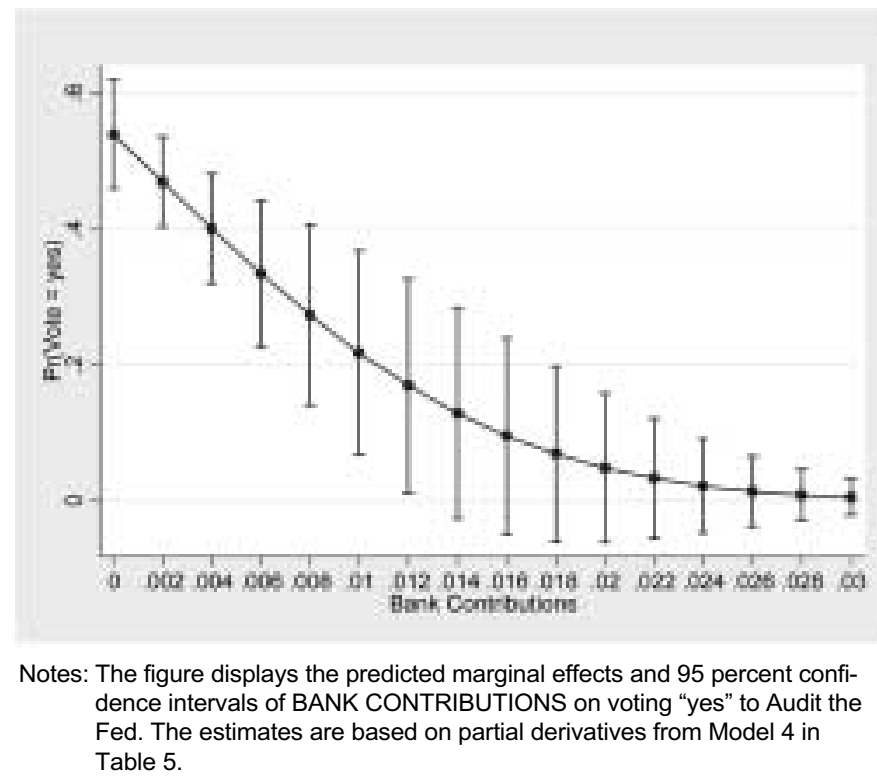

Figures 5 and 6 presents computed marginal effects from Model 4 (Democrats only). Figure 6 illustrates the predictive margins of BANK CONTRIBUTIONS on the probability of voting "yes" on Audit the Fed. According to the figure, there is a 58 percent chance that a Democrat will vote "yes" on the bill when getting a zero share of contributions from money center banks. However, a Democrat that gets just 1 percent of his total contributions from banks is 38 percentage points less likely to favor the bill, with a predicted probability of voting "yes" of 20 percent. Contributions from big banks seem to have large effects even when they comprise relatively small shares of representatives' total receipts. 
Figure 6. Marginal Effects of Dem's Ideology on "Audit the Fed" Voting

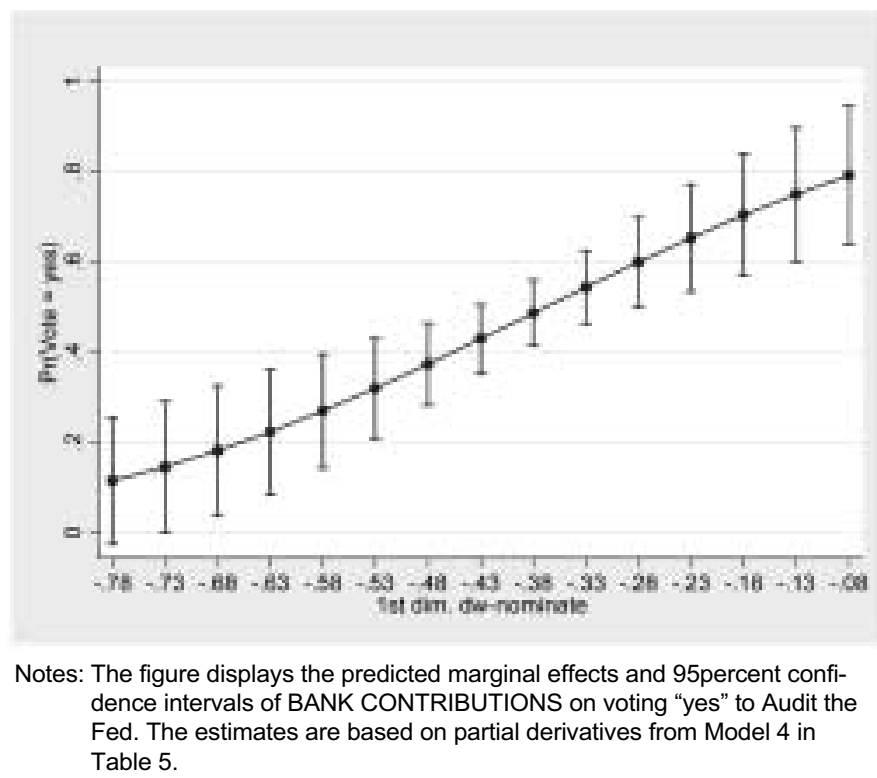

The same holds for member ideology. According to Figure 7, moving DWNOMINATE from the value of the most left-wing Democrat (Jim McDermott, WA-7) to the value of the most right-wing Democrat (Heath Shuler NC-11) increases the odds of voting "yes" on the bill by 67 percentage points. Ideology appears to have a large effect on voting to make the Fed more transparent but the direction of this effect is the reverse of traditional coalition patterns. The Right is now challenging the Fed to be more transparent, more accountable, and less beholden to banks while the Left is positioning itself as the defender of the Fed. I consider this historic reversal in the conclusion.

\section{CONCLUSION}

Due to the rapid globalization of banking in the new millennium, the Federal Reserve was placed in the position of having to provide vast amounts of dollar liquidity to foreign central banks. Had the Fed not supported other central banks with currency swap agreements between 2008 and 2010, the financial crisis in the U.S. would almost certainly have been worse. In a broader sense, the swap networks were central bankers' ad hoc "response to a globalized financial world, 
where there is little or no restriction on the currencies in which global financial intermediaries may borrow or lend, and where central banks can create only one currency but in virtually unlimited quantities" (Destais 2014, 1).

I have explored the foreign and domestic political controversies that swirled around the Fed's swaps agreements. The foreign concern was that, as the issuer of the world's foremost international currency, the Fed holds the power to pick and choose among potential swap counterparties for reasons that are not necessarily financial, but might also be strategic or political. I evaluated this claim and found evidence that the Fed selected foreign central banks for swaps that were important to U.S. financial interests. While I found some support for the Fed's selection criteria, as revealed by the GAO audit, the factor that most strongly and consistently correlates with a central bank obtaining a Fed swap arrangement is the extent to which large U.S. banks held financial claims on a country. This finding suggests that Fed swaps help to safeguard the financial interests of the United States and are motivated primarily by U.S. self-interest.

One implication of this result is that central banks outside the orbit of U.S. financial interests cannot count on the Federal Reserve as a source of dollar liquidity in times of crisis. This may help us understand why some nations are expanding regional reserve pooling arrangements such as the Chiang Mai Initiative (CMI) (Henning 2009). It should be noted that the CMI was not used during the 2008 crisis; instead Japan, South Korea, and Singapore turned to the Fed for support via swap line agreements. This selectively, in turn, helped revitalize the CMI and prompted efforts to expand it to ensure that all members - not just those that are important to U.S. interests - would be able to obtain emergency funding in a crisis. By the same token, efforts to "self-insure" against financial volatility by accumulating large foreign currency reserves have expanded after the crisis (Aizenman, Yothin, and Park 2011). Lastly, Truman (2013) has suggested ways to institutionalize and de-politicize central bank swap arrangements by vesting the IMF with the authority to coordinate these operations. Yet despite the effectiveness of swaps in calming global markets, it is far from clear that U.S. officials would agree to any plan that would limit the Fed's discretion. The broader point is that the power of the Fed to pick and choose counterparties for currency swaps on the basis of U.S. interests creates uncertainty over the provision of global lender-of-last-resort services.

The U.S. Congress poses perhaps an even greater barrier to the expansion and institutionalization of central bank swap networks. As I have shown, the Fed's support for foreign central banks prompted legislation that would allow the GAO Congress's watchdog - to audit all Fed operations, including its transactions with foreign central banks and its open-market operations. I analyzed voting on 
this proposal with the aim of identifying the members of the Fed's support coalition in Congress and found that defenders of the Fed are composed of two distinct groups: representatives that receive campaign contributions from large commercial banks and representatives positioned on the left side of the ideological spectrum. A key result indicates that voting against the Audit the Fed proposal (i.e., supporting the Fed) correlates strongly with the share of campaign contributions representatives receive from the 11 large banks that account for nearly all foreign lending by U.S. banks. In addition, I found that left-leaning representatives also oppose subjecting the Fed's foreign and domestic operations to greater congressional scrutiny while right-leaning members strongly support such audits, even at the risk of a politicizing monetary policy.

With all but one Republican voting "yes", and 97 mostly right-leaning Democrats joining them, the Fed seems to have fallen out of favor with the Right. Put another way, Ron Paul's anti-Fed ideas, which have long been on the fringe, appear to be moving into the mainstream. This is a break from the past since the Right has historically supported the Federal Reserve for its conservative commitment to low inflation.

What is causing this historic reversal? While it is too soon to say with certainly, the analysis suggests that it is not being driven by the hardships that older, conservative home-owning Americans experienced during the crisis. My regressions show no correlation between voting to audit the Fed and district foreclosure rates, district social security beneficiaries, or the share of residents aged 65 and older in a district.

This leaves open the possibility that actions by the Federal Reserve itself during the crisis have fueled the Right's anger toward the central bank. From the Fed's standpoint, the financial crisis downgraded inflation to a second-order concern while it concentrated on restoring financial stability and reviving employment. This shift in focus exposed the Fed to attacks from the Right because rightwing ideology tends to view financial instability as caused by excessive government intervention in the economy. From this perspective, the Fed's emergency loans are "bailouts" that create the moral hazard that incentivizes banks to take on too much risk. In addition, the Fed's support for foreign financial institutions touched another nerve on the Right. The Fed's support for foreign banks and central banks antagonized right-wing legislators who have long opposed U.S. "internationalism," foreign aid, and organizations like the IMF that backstop the international financial system (Milner and Tingley 2011; Broz 2011).

Will the Right's opposition to the Fed persist beyond the current economic downturn and impinge on the Fed's independence? My analysis suggests that the globalization of financial intermediation does pose an important long-run politi- 
cal challenge for the Fed and its supporters. Inasmuch as foreign banks continue to hold substantial liabilities in U.S. dollars, the Fed will be on the hook to act as a global lender of last resort since it is the only central bank that can create dollars freely. While its operations may be increasingly global, the Fed's legitimacy with the Right appears to end at the water's edge, leaving the Fed on the horns of a classic "globalization vs. domestic politics" dilemma (Rodrik 2000). With its political support in the U.S. dwindling, the Fed's continuing extension of liquidity services to foreign central banks will likely provoke greater anti-Fed sentiment from the Right. With Republicans in control of the Senate since the midterm elections of November 2014, the threat might be close at hand since Democrats can no longer block progress of Audit the Fed bills in Congress.

\section{REFERENCES}

Aizenman, Joshua and Gurnain Kuar Pasricha. 2010. "Selective Swap Arrangements and the Global Financial Crisis: Analysis and Interpretation." International Review of Economics and Finance 19(3), 353-365.

Aizenman Joshua, Jinjarak Yothin and Donghyun Park. 2011. "International Reserves and Swap Lines: Substitutes or Complements?" International Review of Economics and Finance 20(1), 5-18.

Allen, William A. and Richhild Moessner. 2010. "Central Bank Co-operation and International Liquidity in the Financial Crisis of 2008-9." Bank for International Settlements Working Papers No. 310 (June).

Baba, Naohik, Robert N McCauley and Srichander Ramaswamy. 2009. "U.S. Dollar Money Market Funds and Non-U.S. Banks.” BIS Quarterly Review (March), 65-81.

Barbieri, Katherine and Omar Keshk. 2012. Correlates of War Project Trade Data Set Codebook, Version 3.o. Accessed at http://correlatesofwar.org (July 10, 2012).

Beck, Thorsten, Asli Demirgüç-Kunt and Ross Levine. 2000. "A New Database on Financial Development and Structure." World Bank Economic Review 14(3), 597-605.

Board of Governors of the Federal Reserve System. 2007. Minutes of the Federal Open Market Committee. Washington D.C.: Board of Governors of the Federal Reserve System.

Bordo, Michael D., Owen Humpage, and Anna J. Schwartz. 2012. "Epilogue: Foreign Exchange Market Operations in the Twenty-First Century." NBER Working Paper No. 17984 (April), 1-21. 
Broz, J. Lawrence. 2005. "Congressional Politics of International Financial Rescues.” American Journal of Political Science 49(3), 479-496.

. 2007. "Congressional Voting on Funding the International Financial Institutions.” The Review of International Organizations 3(4), 351-374. . 2011. "The United States Congress and IMF Financing, 1944-2009." The Review of International Organizations 6(3), 341-368.

Canes-Wrone, Brandice, John F. Cogan and David W. Brady. 2002. "Out of Step, Out of Office: Electoral Accountability and House Members' Voting.” American Political Science Review 96(1), 127-140.

Destais, Christophe. 2014. "Central Bank Currency Swaps and the International Monetary System.” CEPII Policy Brief 5, 1-10.

Felsenthal, Mark and Mohammad Zargham. 2011. "Rep. Paul Planning Hearing on Fed Foreign Lending." Reuters (April, 2). Accessed at http://www.reuters.com/article/2011/04/02/usa-fed-paul-idUSN o214517620110402 (July 1, 2012).

Fleming, Michael. J. and Nicholas J. Klagge. 2010. “The Federal Reserve's Foreign Exchange Swap Lines.” Federal Reserve Bank of New York 16(4), 1-7.

Goldberg, Linda S., Craig Kennedy and Jason Miu. 2011. "Central Bank Dollar Swap Lines and Overseas Dollar Funding Costs.” Economic Policy Review (May), 3-20.

Gould, Erica R. 2003. "Money Talks: Supplementary Financiers and International Monetary Fund Conditionality.” International Organization 57(3), 551586.

Grier, Kevin. 1991. "Congressional Influence on U.S. Monetary Policy: An Empirical Test.” Journal of Monetary Economics 28(2), 201-220.

Havrilesky, Thomas M. 1995. The Pressures on American Monetary Policy. Massachusetts: Kluwer Academic Publishers.

Henning, C. Randall. 2009. "The Future of the Chiang Mai Initiative: An Asian Monetary Fund?” Peterson Institute for International Economics Policy Brief o9-5 (February), 1-9.

Hetzel, Robert L. 1985. “A Congressional Mandate for Monetary Policy.” Cato Journal 5(3), 797-820.

Irwin, Neil. 2013. The Alchemists: Three Central Bankers and a World on Fire. New York: Penguin Press.

Ivashina, Victoria, David S. Scharfstein, and Jeremy C. Stein. 2012. "Dollar Funding and the Lending Behavior of Global Banks.” NBER Working Paper No. 18528 (November), 1-47.

Kane, Edward J. 1982. "External Pressure and the Operations of the Fed." In 
Raymond. E. Lombra and Willard. E. Witte, eds., Political Economy of International and Domestic Monetary Relations, Ames: Iowa State University Press, 211-232.

Levendusky, Matthew S., Jeremy C. Pope and Simon D. Jackman. 2008. "Measuring District-Level Partisanship with Implications for the Analysis of U.S. Elections." The Journal of Politics 70(3), 736-753.

McDowell, Daniel. 2012. "The US as 'Sovereign International Last-Resort Lender': The Fed's Currency Swap Programme during the Great Panic of 2007-09." New Political Economy 17(2), 157-178.

McGuire, Patrick and Goetz von Peter. 2009. "The US Dollar Shortage in Global Banking." Bank for International Settlements Quarterly Review (March), 47-63.

Milner, Helen V. and Dustin H. Tingley. 2011. "Who Supports Global Economic Engagement? The Sources of Preferences in American Foreign Economic Policy.” International Organization 65(1), 37-68.

Obstfeld, Maurice. 2009. "Lenders of Last Resort and Global Liquidity: Rethinking the System." Development Outreach, World Bank of Institute 11(3), 43-46.

Obstfeld, Maurice, Shambaugh, Jay. C. and Alan M. Taylor. 2009. "Financial Instability, Reserves, and Central Bank Swap Lines in the Panic of 2008." American Economic Review: Papers \& Proceedings 99(2), 480-486.

Peterson, Kristina and Siobhan Hughes. 2012. "House Passes Ron Paul's 'Audit the Fed' Bill." Real Time Economics from The Wall Street Journal. Accessed at http://blogs.wsj.com/economics/2012/07/25/house-passes-ron-pauls-audit-the-fed-bill/ (September 10, 2013).

Poole, Keith T. and Howard Rosenthal. 2000. Congress: A Political-Economic History of Roll Call Voting. New York: Oxford University Press.

Rodrik, Dani. 2000. "How Far Will International Economic Integration Go?" Journal of Economic Perspectives 14(1), 177-186.

Sheng, Andrew. 2014. "Central Bank Currency Swaps Key to the International Monetary System." East Asia Forum Accessed at http://www.eastasiaforum.org/2014/04/o1/central-bank-currency-swaps-key-to-international-monetary-system (September 10, 2014).

Shin, Hyun Song. 2012. "Global Banking Glut and Loan Risk Premium.” IMF Economic Review 60(2), 155-192.

Stewart III, Charles and Jonathan Woon. 2011. "Congressional Committee Assignments, 103rd to 112th Congresses, 1993-2011." House (March 20). Accessed at http://web.mit.edu/17.251/www/data_page.html (July 1, 2012). 
Truman Edwin. M. 2013. "Enhancing the Global Financial Safety Net through Central-bank Cooperation." Accessed at http://www.vox.eu.org (September 10, 2014).

United States General Accounting Office. 2011. Federal Reserve System: Opportunities Exist to Strengthen Policies and Processes for Managing Emergency Assistance. GAO-11-696. 21 July.

[Received May 29, 2015; Revised J uly 23, 2015; Accepted J uly 29, 2015] 